\title{
PENERTIBAN IZIN MENDIRIKAN BANGUNAN (IMB) DI KECAMATAN KUTA UTARA KABUPATEN BADUNG
}

\author{
I Gede Andhika Kusuma Darsana, I Ketut Kasta Arya Wijaya, Luh Putu Suryani \\ Fakultas Hukum, Universitas Warmadewa, Denpasar-Bali, Indonesia \\ Dedikandhika111@gmailcom, kastaaryawijaya@gmailcom, Putusuryani099@gmailcom
}

\begin{abstract}
Abstrak
Pencegahan terhadap pelanggaran izin mendirikan bangunan diatur dalam peraturan daerah dimana setiap daerah memiliki kekuasaannya sendiri yang disebut sebagai daerah otonom yang memiliki lembaga yang bertugas dalam penertiban izin mendirikan bangunan yang ditangani oleh Satuan Polisi Pamong Praja. Penelitian ini bertujuan untuk mengetahui kewenangan pemerintah daerah dalam menertibkan Izin Mendirikan Bangunan dan menganalisis penegakan hukum terhadap bangunan yang belum memiliki Izin Mendirikan Bangunan (IMB) di Kecamatan Kuta utara Kabupaten Badung. Penelitian ini didesain dengan menggunakan penelitian hukum empiris. Hasil penelitian menunjukan bahwa kewenangan pemerintah daerah dalam menertibkan izin mendirikan bangunan bertujuan untuk mengatur hubungan hukum antara warga Negara dengan bangunan-bangunan yang menjadi objek penertiban dalam rangka untuk mencegah terjadinya tata ruang yang tidak sesuai dengan aturan. Selanjutnya, setiap warga di Kecamata Kuta Utara yang memiliki bangunan atau akan membangun bangunan wajib memiliki surat izin sesuai dengan peraturan yang dikeluarkan oleh pemerintah daerah. Kemudian, penegakan hukum terhadap bangunan yang belum memiliki Izin Mendirikan Bangunan (IMB) dengan memberikan Surat Peringatan sebanyak 3 kali. Apabila pemilik bangunan tetap tidak menghiraukan Surat Peringatan tersebut maka dilakukan pembongkaran oleh Satuan Polisi Pamong Praja sesuai Surat Keputusan dari kepala daerah (Bupati).
\end{abstract}

Kata Kunci: Penertiban bangunan liar, Satuan Polisi Pamong Praja, Izin Mendirikan Bangunan.

\begin{abstract}
Prevention of violations of building construction permits is regulated in a regional regulation where each region has its own power which is called an autonomous region which has an institution in charge of controlling building permits handled by the Civil Service Police Unit. This study aims to determine the authority of local governments in regulating building permits and to analyze law enforcement on buildings that do not have a building permit (IMB) in North Kuta District, Badung Regency. This study was designed using empirical legal research. The results show that the authority of the local government in controlling building permits aims to regulate the legal relationship between citizens and buildings that are objects of control in order to prevent spatial planning that is not in accordance with the rules. Furthermore, every resident in North Kuta District who owns a building or will build a building is required to have a permit in accordance with the regulations issued by the local government. Then, law enforcement for buildings that do not yet have a Building Construction Permit (IMB) by providing a warning letter 3 times. If the building owner still ignores the Warning Letter, the Civil Service Police Unit will demolish it according to the Decree from the regional head (Bupati).
\end{abstract}

Keywords: Control of illegal buildings, Civil Service Police Unit (Satpol PP), Building Construction Permit

\section{PENDAHULUAN}

Negara Indonesia merupakan negara agraris yang sangat besar, sehingga memerlukan suatu kepastian hukum dalam mengatur setiap tindakan warganya yang mana diatur secara pasti dalam Undang-Undang Dasar 1945 dan dijadikan sebagai pedoman. Setiap tindakan yang dilakukan oleh masyarakat harus berdasarkan pada hukum yang berlaku di Negara Kesatuan Republik Indonesia. Apabila terdapat masyarakat melakukan pelanggaran akan dikenakan sanksi sesuai dengan aturan yang berlaku. Pelanggar aturan tersebut akan dikenakan suatu hukuman yang pantas bagi sipelanggar. Contohnya pelanggar Hukum Administrasi negara akan dikenakan sanksi berupa denda administrasi atas apa yang telah di perbuatnya.

Hukum Administrasi Negara adalah peraturan hukum yang mengatur administrasi yaitu hubungan antara warga Negara dan pemerintahan yang menjadi sebab sehingga Negara itu berfungsi (Nur, 2015). Hukum administrasi Negara ini mengatur tentang bagaimana suatu perangkat Negara menjalankan 
tugasnya sehingga suatu pejabat Negara dapat menjalankan tugasnya masing-masing sesuai wewenang yang telah ditentukan, sehingga dapat tercapainya tujuan yang telah ditentukan oleh suatu Negara. Tujuan yang telah ditentukan oleh suatu Negara adalah menciptakan ide-ide hukum menjadi kenyataan, sehingga dapat terciptanya Negara yang aman damai tentram dan harmonis. Untuk mempermudah mewujudkan tujuan dari suatu Negara maka dibentuklah daerah otonom.

Daerah otonom merupakan kesatuan masyarakat hukum yang mempunyai batasan wilayah yang berwenang mengatur dan mengurus pemerintahan setempat menurut prakarsa sendiri berdasarkan aspirasi masyarakat dalam sistem Negara Kesatuan Republik Indonesia (Suriansyah, 2008). Dalam sistem Negara Kesatuan Republik Indonesia ada yang dinamakan izin yang merupakan sesuatu yang boleh atau tidak diperbolehkan yang diberikan baik kepada seseorang maupun organisasi untuk menjalankan tugasnya. Melalui izin pemerintah terlibat dalam kegiatan mengarahkan warga melalui instrumen berupa izin. Izin yang diberikan pemerintah. Kadang kala, terlibat dalam kegiatan masyarakat bahkan tidak berhenti pada satu tahap melainkan melalui serangkaian kebijakan.

Setelah izin diperoleh dilakukan pengawasan pemegang izin dan diwajibkan menyampaikan laporan secara berkala dan sebaliknya pemerintah melakukan pengendalian terhadap kegiatan masyarakat dengan menggunakan instrumen perizinan izin dimaksudkan untuk mencapai berbagai tujuan tertentu (Helmi, 2012). Tujuan tertentu yang dimaksudkan adalah penerapan aturan hukum yang berlaku sampai saat ini. Tetapi, nyatanya sampai sekarang masih banyak masyarakat yang masih melanggar aturan yang berlaku terutama pada peraturan Izin Mendirikan Bangunan (IMB) terutama di wilayah Kecamatan Kuta utara, Kabupaten Badung. Di wilayah Kecamatan Kuta Utara, Kabupaten Badung terdapat banyak bangunan yang asal dibangun dan ditempati baik untuk usaha atau untuk tempat tinggal yang tidak memenuhi aturan pemerintah berdasarkan persyaratan setiap warga Negara harus memiliki Izin Mendirikan Bangunan (IMB).

Izin Mendirikan Bangunan yang masih saja dilanggar oleh masyarakat di persoalkan karena banyak masyarakat yang belum mengetahui fungsi dari izin mendirikan bangunan. Izin yang dikeluarkan pemerintah atas pemanfaatan tanah dan sumber daya alam mempunyai posisi yang kuat dalam bingkai hukum negara (state law) terlebih jika berhadapan dengan hak atas tanah masyarakat (Jayantiari \& Wijaya, 2017) karena masyarakat yang belum memiliki izin mendirikan bangunan mereka berpikir bahwa sementara belum ada tindakan tegas dari pemerintah tentang pemilik bangunan yang belum miliki izin mendirikan bangunan.

Beberapa penelitian serupa pernah dikaji sebelumnya yang membahas rumusan berbeda dari rumusan penelitian ini. Salah satu penelitian serupa yang dimaksud adalah penelitian tentang pelayanan Izin Mendirikan Bangunan (IMB) dalam mencapai kualitas pelayanan publik yang optimal (Oktariyanda, Zauhar, \& Rochmah, 2013). Selain itu, penelitian lainnya adalah penelitian tentang implementasi kebijakan perda no. 7 tahun 1992 tentang IMB (Izin Mendirikan Bangunan) di kota Surabaya (Lukman, 2008). Terakhir tentang model efektivitas kebijakan pelayanan Izin Mendirikan Bangunan (IMB) berbasis tata ruang lingkungan yang hijau di kota Palembang (Lionardo, Kurniawan, \& Umanailo, 2020).

Berdasarkan penjelasan di atas, maka penelitian yang baru ini bertujuan untuk mengetahui kewenangan pemerintah daerah dalam menertibkan izinmendirikan bangunan di Kecamatan Kuta Utara Kabupaten Badung dan mengetahui penegakan hukum terhadap bangunan yang belum memiliki izin mendirikan bangunan (IMB).

\section{METODE PENELITIAN}

Tipe penelitian yang digunakan adalah tipe penelitian hukum empiris. Penelitian ini bertujuan unutk melakukan pencarian terhadap pengetahuan yang benar (ilmiah) karena hasil pencarian ini akan dipakai untuk menjawab permasalahan tertentu. Dengan kata lain, penelitian (research) yaitu dari ketidaktahuan dan berakhir pada keraguan dan dari keraguan berakhir pada suatu hipotesis (jawaban yang untuk sementara dapat dianggap benar sebelum dibuktikan sebaliknya) (Amiruddin \& Zainal, 2012). Pendekatan-pendekatan yang dilakukan dalam penelitian ini adalah menggunakan pendekatan Perundang-Undangan dan Pendekatan Fakta Pendekatan Perundang-Undangan digunakan untuk meneliti berbagai aturan hukum yang menjadi tema dalam penelitian ini. Pendekatan fakta digunakan untuk mengkaji peraturan Perundang-Undangan terhadap fakta yang terjadi dilapangan.

Sumber hukum yang digunakan dalam penelitian ini terbagi beberapa bentuk, yaitu: 1) bahan Hukum Primer, aitu bahan hukum yang mengikat dan memiliki kekuatan hukum seperti peraturan 
Perundang-Undangan. 2) Bahan Hukum Sekunder, yaitu bahan-bahan yang isinya membahas hukum primer seperti buku-buku hukum laporan penelitian serta jurnal-jurnal hukum. 3) Bahan Hukum Tersier, yaitu bahan-bahan yang memberikan petunjuk maupun penjelasan terhadap bahan hukum primer dan bahan hukum sekunder yang berupa ensiklopedia kamus dan sebagainya.

\section{HASIL DAN PEMBAHASAN}

\section{Kewenangan Pemerintah Daerah dalam Menertibkan Kepemilikan Izin Mendirikan Bangunan di Kecamatan Kuta Utara Kabupaten Badung}

a. Fungsi dan tujuan izin mendirikan bangunan

Lembaga yang Berwenang Menertibkan Izin Mendirikan Bangunan yaitu pemerintah. Pemerintahan memiliki fungsi untuk memerintah seluruh departemen pemerintahan, badan- badan serta instansiinstansi yang ada dalam dinas-dinas pemerintahan supaya menjalankan kewenangan dan kewajiban pemerintahan dalam suatu Negara. Tujuannya, gar disetiap Negara memiliki suatu instansi yang benarbenar bertanggung jawab dalam melaksanakan tugas-tugas penting negara yang memiliki ketetapan perbuatan pemerintahan. URosenthal merumuskan bahwa pemerintahan secara umum merupakan keseluruhan struktur dan proses-proses di dalam mana terlibat kebijaksanaan- kebijaksanaan dan keputusan-keputusan yang bersifat mengikat untuk dan atas nama kehidupan Bersama (Yani \& Ujud, 2018). Dalam mengatur fungsi dan penugasannya Negara memberikan wewenang penuh kepada Pemerintahan.

Fungsi dari tugas pemerintahan adalah menjamin kesejahteraan rakyatnya dan memecahkan masalah yang diterima atau dihadapi rakyatnya sesuai prosedur dan tanggung jawab pemerintahan berdasarkan pada hukum yang berlaku pada Negara dan juga sebagai pelayanan dalam masyarakat guna kepentinga-kepentingan rakyat yang ada dalam kehidupan bermasyarakat. Dalam kehidupan bermasyarakat kita berpedoman pada hukum karena kita hidup di Negara hukum kita tidak hanya memiliki hukum tertulis saja tetapi juga memiliki hukum tidak tertulis atau keputusan hakim yang sebagaimana dilihat dari tindakan atau perbuatan yang belum diatur dalam hukum tertulis jadi hakim lah yang bisa memutuskan suatu perkara dan menjatuhkan hukuman nya selama aturan itu belum dibuat karena dalam sistem Anglo Saxon hakim lah yang sebagai raja. Hakim dalam mengeluarkan keputusannya tidak sewenang-wenang bisa melakukan kehendak sendiri tetapi hakim juga harus mendasar kepada Undang-Undang Dasar 1945. Adapun suatu aturan yang dikeluarkan oleh pemerintah yaitu Izin mendirikan bangunan atau IMB; merupakan perizinan yang diberikan oleh kepala daerah kepada pemilik bangunan untuk melakukan pembangunan baru mengubah memperluas mengurangi dan/atau merawat bangunan sesuai dengan persyaratan administratif dan persyaratan teknis yang berlaku.

Dalam persyaratan yang berlaku Izin mendirikan bangunan (IMB) juga memiliki fungsi dan tujuan, yaitu 1) mendapatkan kepastian dan perlindungan hukum pada bangunan yang telah di bangun agar ketika bangunan tersebut berdiri tidak akan mengganggu atau merugikan orang lain. 2) Harga jual bangunan meningkat karena jika rumah yang sudah memiliki izin mendirikan bangunan (IMB). 3) Dapat dengan mudah mencari pinjaman bank karena jika pemilik rumah akan meminjam uang pada bank dengan menggunakan jaminan rumah yang di miliki orang tersebut maka pihak bank pasti akan meminta suatu surat izin mendirikan bangunan. 4) Menjadi persyaratan wajib untuk mengubah hak guna bangunan menjadi sertifikat hak milik karena hak guna bangunan memiliki status hukum yang lebih rendah dibandingkan sertifikat hak milik. 5) Untuk menjaga ketertiban keselarasan kenyamanan dan keamanan dari suatu bangunan yang dimiliki dan juga memiliki fungsi 2 Kewenangan pemerintah daerah Kabupaten Badung dalam penertiban izin mendirikan bangunan.

Segala jenis perbuatan atau tindakan yang dilakukan haruslah tunduk kepada hukum yang berlaku di wilayah Republik Indonesia termasuk juga aturan tentang kewenangan yang dimiliki oleh pemerintah daerah. Pemerintah daerah mengeluarkan berupa peraturan daerah, kabupaten badung yang dibuat dalam hal penertiban izin mendirikan bangunan (IMB) yang juga dilaksanakan pada suatu daerah di Kecamatan Kuta Utara, Kabupaten Badung yang tertuang secara tegas dalam Peraturan Daerah Kabupaten Badung Nomor 27 Tahun 2013 Tentang Penyelenggaraan Izin Mendirikan Bangunan. Penyelenggaraan izin mendirikan bangunan yang dibuat oleh lembaga Negara khususnya di setiap daerah pasti memiliki suatu lembaga yang berperan dalam hal pelaksanaan tugas-tugas daerah untuk mencapai tujuan Negara atau tujuan bersama dalam menjalankan kehidupan di masyarakatdi Indonesia ada yang dinamakan lembaga Negara. 
Lembaga Negara ini memiliki peran yang sangat penting untuk melangsungkan tujuan dari suatu Negara. Tanpa adanya lembaga yang memimpin, maka tujuan Negara akan terhambat. Jadi, Negara membentuk suatu lembaga yang memiliki tugas-tugas tertentu. Tugas-tugas dari lembaga Negara yaitu seperti menciptakan masyarakat yang aman, tentram, damai dan harmonis. Lembaga yang ada dalam suatu Negara sudah pasti memiliki tugas khusus dalam menjalankan tugas sesuai tanggung jawab yang dimilikinya. Dalam hal ini, tanggung jawab yang dimiliki oleh Dinas perizinan yaitu mengeluarkan izin. Pada Setiap izin ada yang namanya pengawasan pembinaan dan/atau penindakan. Dalam hal ini terkait dengan dinas pengampu yang mengeluarkan izin adalah dinas perizinan atau yang disebut sebagai Dinas Penanaman Modal dan Pelayanan Terpadu Satu Pintu (DPMPTSP) dan Dinas Pelayanan Umum (PU). Pelayanan publik dapat didefinisikan sebagai serangkaian aktifitas yang dilakukan oleh birokrasi publik untuk memenuhi kebutuhan warga pengguna (Yonanda, Makmur, \& Adiono, 2013).

Dinas Penanaman Modal Dan Pelayanan Terpadu Satu Pintu mengeluarkan perizinan tetapi tetap berkoordinasi pada Dinas Pelayanan Umum karena secara teknis yang juga menyangkut tentang izin dari mendirikan bangunan adalah Dinas Pelayanan Umum yang memiliki wewenang dalam teknis bangunan dan tata ruang. Selain dari instansi tersebut, ada instansi penindakan atau penegakan hukum, dalam hal terjadinya pelanggaran dalam mendirikan bangunan yang ada kewenangannya pada Satuan Polisi Pamong Praja (SATPOL PP) tetapi dalam menjalankan tugasnya satuan polisi pamong praja tetap mengedepankan pembinaan bukan hanya mengutamakan penindakan. Dalam mengedepankan pembinaan adapun peran terhadap pengawasan di bidang pembangunan satuan polisi pamong praja lah yang memiliki peran mulai dari nol atau mulai dari sebelum membangun sampai dengan mendirikan bangunan sampai dengan adanya pemanfaatan dari bangunan tersebut Satuan Polisi Pamong Prajalah yang memiliki wewenang tersebut. Satuan Polisi Pamong Praja memiliki peran mengantarkan atau menggiring warga untuk mengurus perizinan pada instansi perizinan yang terkait dalam pembangunan tersebut supaya pembangunan dapat berjalan sesuai dengan prosedur yang berlaku.

b. Penegakan hukum terhadap bangunan yang belum memiliki Izin Mendirikan Bangunan (IMB) Kebijakan yang dibuat oleh pemerintah Kabupaten Badung yang berupa peraturan daerah. Ini adalah sebagai ide-ide hukum yang dibuat oleh pemerintah Kabupaten Badung guna menyelaraskan atau menjalankan peraturan yang lebih tinggi yaitu Undang-Undang Nomor 28 Tahun 2002 tentang Bangunan Gedung. Dalam menyelaraskan aturan yang ada haruslah berdasarkan pada asas-asas yang berlaku agar tidak terjadi penyimpangan aturan antara Undang-Undang yang lebih tinggi dengan Undang-Undang yang lebih rendah dan ide-ide hukum dari pemerintah daerah pun dapat terwujudkan dan dapat dilaksanakan dengan lebih mudah pada setiap-setiap daerah yang diperintahnya. Pemerintah daerah memiliki upaya khusus dalam menyelaraskan aturan yang berlaku yaitu dengan mengeluarkan Peraturan Daerah Kabupaten Badung Nomor 27 Tahun 2013 tentang Penyelenggaraan Izin Mendirikan Bangunan adapun macam-macam sanksi dalam penegakan hukum Pasal 30 ayat (1) "Dalam rangka pelaksanaan pengawasan dan pengendalian, Bupati menjatuhkan sanksi administratif berupa:

a) Peringatan tertulis.

b) Pembatasan kegiatan pembangunan.

c) Penghentian sementara pembangunan dan pembekuan IMB D. Penghentian tetap pembangunan.

d) Pencabutan IMB.

e) Surat perintah pembongkaran bangunan.

Selain itu, Pasal 39 ayat (1) "setiap orang yang melanggar ketentuan sebagaimana di maksud dalam pasal 5 ayat (1) pasal 18 ayat (1) pasal 19 ayat (1) pasal 20 ayat (1) dan ayat (2) pasal 21 pasal 22 pasal 32 ayat (3) dipidana dengan kurungan paling lama 6 (enam) bulan atau denda paling banyak Rp 5000000000 (lima puluh juta rupiah)."

\section{Implementasi Prosedur Penegakan Hukum Izin Mendirikan Bangunan di Kecamatan Kuta Utara Kabupaten Badung}

Prosedur penegakan hukum IMB sebaiknya didasarkan pada pelayanan yang tergolong cepat dan tidak berbelit-belit, penyelesaian pelayanan tepat waktu, biaya pengurusan IMB setiap tarif bangunan tidak sama, sosialisasi dengan cara tatap muka dan, pengawasan dilakukan secara langsung dan tidak langsung (Hidayati, 2016). 
Dari setiap aturan yang dikeluarkan oleh pemerintah baik itu dari pemerintah daerah maupun dari pemerintah pusat pasti ada yang tidak sesuai dengan masyarakat. Akibatnya, banyak masyarakat yang tidak mematuhinya baik secara sengaja maupun secara tidak sengaja. Aturan yang dibuat oleh pemerintah baik dari pemerintah pusat maupun pemerintah daerah harus dipatuhi dan bersifat memaksa karena kita hidup di Negara hukum.

Adapun yang disebut sebagai lembaga penegak hukum terutama lembaga penegak hukum di bidang penertiban izin mendirikan bangunan yang disebut sebagai Satuan Polisi Pamong Praja. Satuan Polisi Pamong Praja memiliki bentuk upaya yang sudah dilakukan dalam penertiban bangunan yaitu upaya preventif persuasif (pencegahan) yang dilakukan dengan pengawasan melalui kegiatan patroli tetap yang ada pada setiap wilayah yang beroperasional selama 24 jam untuk menghindari adanya pelanggaran-pelanggaran. Tetapi, masih tetap saja ada warga yang melakukan pelanggaran seperti contohnya ada 52 bangunan yang dianggap melakukan pelanggaran oleh patroli pengawasan dari bulan Mei sampai dengan bulan Agustus tetapi pemerintah tetap masih mengedepankan upaya preventif persuasif (pencegahan) walaupun ada warga yang melakukan pelanggaran.

Dalam penegakan hukum terhadap bangunan yang belum memiliki izin mendirikan bangunan, pemerintah daerah juga mempunyai upaya khusus. Upaya khusus yang dimiliki pemerintah daerah yaitu berupa Peraturan Daerah Kabupaten Badung Nomor 27 Tahun 2013 tentang Penyelenggaraan Izin Mendirikan Bangunan adapun isi dari pasal-pasal tersebut yaitu Pasal 5 ayat (1) "Setiap orang yang akan mendirikan bangunan wajib memiliki Izin Mendirikan Bangunan.

Walaupun sudah ada peraturan pemerintahan yang mengatur ketertiban masyarakat tidaklah peraturan tersebut terlaksana dengan mudah dapat dilihat sebagai contoh yang ada pada Kecamatan Kuta Utara, Kabupaten Badung masih ada orang- orang yang melanggar aturan terutama pada peraturan daerah nomor 27 tahun 2013 tentang penyelenggaraan izin mendirikan bangunan masih ada bangunan yang belum memiliki izin mendirikan bangunan yaitu terdapat 52 bangunan yang masih melakukan pelanggaran sehingga peraturan daerah tersebut belum benar-benar terlaksana dengan efektif.

\section{SIMPULAN DAN SARAN}

\section{Simpulan}

Kewenangan pemerintah daerah dalam menertibkan izin mendirikan bangunan di Kecamatan Kuta Utara Kabupaten Badung yaitu bertujuan untuk mengatur hubungan-hubungan hukum antara warga Negara dengan bangunan-bangunan yang menjadi objek penertiban izin terkait dengan izin mendirikan bangunan dalam rangka untuk mencegah terjadinya tata ruang yang tidak sesuai dengan aturan. Kemudian, setiap warga di Kecamata Kuta Utara yang memiliki bangunan atau akan membangun wajib memiliki surat izin mendirikan bangunan sesuai dengan peraturan yang dikeluarkan oleh pemerintah daerah. Apabila terjadinya pelanggaran, Bupati sebagai kepala daerah dapat menjatuhkan hukuman berupa sanksi administrative.

Kemudian, penegakan hukum terhadap bangunan yang belum memiliki izin mendirikan bangunan di Kecamatan Kuta Utara Kabupaten Badung dilakukan oleh Satuan Polisi Pamong Praja Kabupaten Badung yang memiliki upaya mengedepankan pembinaan atau pencegahan terhadap bangunan yang belum memiliki izin mendirikan bangunan yaitu dengan upaya memberikan surat peringatan sebanyak 3 kali Dan apabila pemilik bangunan tetap tidak menghiraukan surat peringatan tersebut maka dilakukan penegakan oleh satuan polisi pamong praja yaitu dengan dikeluarkannya surat keputusan Bupati yaitu pembongkaran.

\section{Saran}

Melalui penelitian ini diharapkan untuk semua warga Negara Indonesia agar lebih mematuhi dan memperhatikan aturan yang sudah berlaku karena kita hidup di Negara hukum Untuk pemerintah agar lebih tegas dalam menjalankan aturan yang berlaku tanpa memandang siapa yang melakukan pelanggaran terutama pemerintah daerah karena pemerintah daerah memiliki wewenang terhadap daerah kekuasaannya Untuk warga yang ingin melakukan pembangunan agar lebih teliti dan melihat aturan yang berlaku di setiap daerah dalam melakukan pembangunan karena setiap daerah memiliki kewenangannya masing-masing. Selanjutnya, ntuk setiap warga haruslah mematuhi aturan yang berlaku sebelum dilakukannya penegakan hukum terhadap aturan yang telah dilanggar dan harus lebih sadar akan tujuan dari dibentuknya peraturan tersebut Untuk pemerintah daerah wajiblah dengan tegas menindak pelanggar peraturan daerah agar kemungkinan warga yang melanggar lebih sedikit tidak 
seperti saat ini karena kurang tegasnya pemerintah dalam penegakan sehingga masih banyaknya warga yang melanggar atau tidak menghiraukan aturan yang belaku.

\section{DAFTAR PUSTAKA}

Amiruddin, \& Zainal, A. (2012). Pengantar Metode Penelitian Hukum (IV). Jakarta: PT Raja Grafindo Persada. Helmi. (2012). Hukum Perizinan Lingkungan Hidup. Jakarta: Sinar Grafika.

Hidayati, H. (2016). Pelaksanaan Pelayanan Izin Mendirikan Bangunan (IMB) (Studi Pada Kantor Pelayanan Perizinan Terpadu (KP2T) Dan Dinas Pekerjaan Umum Dan Perumahan (PU) Kota Blitar). Jurnal Administrasi Publik, 4(3).

Jayantiari, I. G. A. M. R., \& Wijaya, I. K. K. A. (2017). Tinjauan Yuridis Pengaturan Tanah Druwe Desa Di Bali (Aspek Hukum Perlindungan Masyarakat Adat Atas Tanah). WICAKSANA: Jurnal Lingkungan Dan Pembangunan, $1(1)$.

Lionardo, A., Kurniawan, R., \& Umanailo, M. C. B. (2020). An effectiveness Model of Service Policy of Building Permit (IMB) based on A Green Spatial Environment in Palembang City. Proceedings of the International Conference on Industrial Engineering and Operations Management, O(March), 2588-2596.

Lukman, A. (2008). Implementasi Kebijakan Perda No. 7 Tahun 1992 Tentang IMB (Izin Mendirikan Bangunan) Di Kota Surabaya. Jurnal Ilmu-Ilmu Sosial, 8(2), 84-91.

Nur, Y. (2015). Pengantar Hukum Administrasi Negara Indonesia. Jakarta: Mitra Wacana Media.

Oktariyanda, T. A., Zauhar, S., \& Rochmah, S. (2013). Pelayanan Izin Mendirikan Bangunan (IMB) dalam Mencapai Kualitas Pelayanan Publik yang Optimal. Jurnal Wacana Sosial Dan Humaniora, 16(4), 179185.

Suriansyah, M. (2008). Dinamika Hukum Pemerintah Daerah Sejak Kemerdekaan Sampai Era Reformasi. Laksbang: Mediatama.

Yani, A. R. A., \& Ujud, R. (2018). Sistem Pemerintahan Indonesia. Yogyakarta: CV Budiutama.

Yonanda, I., Makmur, M., \& Adiono, R. (2013). Efektivitas Pelayanan Izin Mendirikan Bangunan (IMB) Dalam Sektor Industri Pariwisata Di Kota Batu (Studi Pada Kantor Pelayanan Perizinan Terpadu Kota Batu). Jurnal Administrasi Publik (JAP), l(1). 